\title{
Induction of CMV-1 promoter by 4-hydroxy-2-nonenal in human embryonic kidney cells ${ }^{\star}$
}

\author{
Morana Jaganjac1,\#, Tanja Matijevic1,\#, Marina Cindric¹, Ana Cipak', Lidija Mrakovcic', \\ Wolfgang Gubisch² and Neven Zarkovic ${ }^{\circledR}$ \\ 'Department of Molecular Medicine, Rudjer Boskovic Institute, Zagreb, Croatia; ${ }^{2 B i o m e d i c a ~ M e d i z i n p r o d u k t e ~ G m b H ~ \& ~ C o ~ K G, ~ W i e n, ~ A u s t r i a ~}$
}

\begin{abstract}
Oxidative stress, i.e., excessive production of oxygen free radicals and reactive oxygen species, leads to lipid peroxidation and to formation of reactive aldehydes which act as second messengers of free radicals. It has previously been shown that oxidative stress may be involved in the transcriptional regulation of cytomegalovirus (CMV) immediate early promoter, involved in viral reactivation from latency. In the current study we used a plasmid containing the yellow fluorescent protein (YFP) gene under the control of CMV-1 promoter to monitor the influence of hydrogen peroxide and reactive aldehydes, 4-hydroxy-2-nonenal (HNE) and acrolein, on CMV-1 promoter activation in human embryonic kidney cells (HEK293). While acrolein was ineffective, hydrogen peroxide slightly (50\%) stimulated the CMV promoter. In contrast, HNE had a strong, up to 3-fold, enhancing effect on the CMV-1 promoter within four as well as after $24 \mathrm{~h}$ of treatment. The most effective was the treatment with $24 \mu \mathrm{M}$ HNE. This effect of HNE suggests that stressful conditions associated with lipid peroxidation could lead to CMV activation.
\end{abstract}

Key words: 4-hydroxy-2-nonenal, oxidative stress, cytomegalovirus Received: 10 November, 2009; revised: 22 April, 2010; accepted: 14 May, 2010; available on-line: 31 May, 2010

\section{INTRODUCTION}

Oxidative stress has been associated with the pathogenesis of many diseases. Oxidative stress is a balance shift of oxido-reductive reactions towards oxidation, resulting in excessive production of reactive oxygen species (ROS). Although most of the ROS are radical species like hydroxyl and superoxide radical, there are also non-radical species like hydrogen peroxide. ROS are normally formed in small quantities during metabolic processes, however, overproduction of ROS is cytotoxic and damages macromolecules (DNA, proteins, sugars and lipids) (Esterbauer et al., 1991; Bartosz, 2009). Polyunsaturated fatty acids in membranes as well as storage lipids are subject to ROS-induced peroxidation resulting in the destruction of biomembranes. Final products of lipid peroxidation are reactive aldehydes like 4-hydroxy2-nonenal (HNE), malondialdehyde, acrolein and other $\alpha, \beta$-unsaturated aldehydes (Esterbauer et al., 1991; Uchida, 2003). The lipid-derived aldehydes are more stable than ROS and therefore can diffuse to targets remote from the initial oxidative injury site. Among these aldehydes, HNE, also denoted as a "second messenger of free radicals", is of particular biochemical and bio- medical relevance (Esterbauer et al., 1991; Zollner et al., 1991; Zarkovic et al., 1999). Since HNE is formed during oxidative stress, it is not surprising that many deleterious effects have been attributed to it. These include a depletion of glutathione (Hartley et al., 1995) and inhibition of DNA and protein synthesis (Esterbauer et al., 1991). Furthermore, HNE has been shown to play a role in modulation of cell growth (Hartley et al., 1995; Zarkovic et al., 1993; 1994; 1995), differentiation (Cheng et al., 1999; Rinaldi et al., 2000; Borovic-Sunjic et al., 2005), apoptosis (Cheng et al., 1999; Uchida et al., 1999; Sovic et al., 2001; Borovic-Sunjic et al., 2005), and cell signaling (Kreuzer et al., 1998; Cheng et al., 1999; Awasthi et al., 2004). HNE is also very effective in binding to DNA or proteins leading to adduct formation, eliciting mutagenic or carcinogenic effects (Esterbauer et al., 1991; Sovic et al., 2001; Zarkovic, 2003).

Cytomegalovirus (CMV) is a widespread pathogen which latently infects the majority of adults and is responsible for generally asymptomatic and persistent infections in healthy people (Mocarski, 1996). However, primary infection or reactivation in immunosuppressed patients (e.g., after solid organ or bone marrow transplantation) or immunologically immature individuals may cause a severe disease and is associated with serious morbidity or mortality (Numazaki et al., 1995). The mechanism by which CMV reactivates from latency in immunocompromised individuals is not well understood. Scholz and coworkers have reported that oxidative stress may contribute to the regulation of CMV replication, virus shedding, and the activation of endothelial cells by proinflammatory cytokines (Scholz et al., 1996). The replication cycle of a human $\mathrm{CMV}$ is characterized by the expression of immediate early (IE), early (E), and late (L) gene regions. Since IE gene expression had previously been described to be of crucial relevance to CMV pathogenesis (Scholz et al., 2001), the aim of this study was to investigate the impact of $\mathrm{HNE}$ on $\mathrm{CMV}-1$ promoter induction. CMV-1 originates from the IE gene of human CMV (CMV-IE) and is one of the most commonly

\footnotetext{
e-mail: zarkovic@irb.hr

* Presented at the COST B-35 Work Group 4 Open Workshop "Natural and synthetic antioxidants", September 25-26, 2009, Rzeszów, Poland.

"Both authors contributed equally to this study

Abbreviations: CMV, cytomegalovirus; DMEM, Dulbecco's modified Eagle's medium; FCS, fetal calf serum; HBSS, Hanks' balanced salt solution; HEK293, 293 human embryonic kidney cells; HNE, 4-hydroxy-2-nonenal; HNE-DMA, 4-hydroxy-2-nonenal-dimethylacetal; $\mathrm{LD}_{50}$ lethal dose $50 \%$; RFU, relative fluorescence units; $R O S$, reactive oxygen species; TLR4, Toll-like receptor 4; YFP, yellow fluorescent protein.
} 
used promoters. The CMV-IE promoter region contains a high density of transcription factor-binding sites. These sites include multiple 18-, 19- and 21-bp repeated motifs that bind the transcription factors $\mathrm{NF}-x \mathrm{~B} / \mathrm{rel}, \mathrm{CREB} /$ ATF and Sp1, respectively. In addition, it contains binding sites for AP1, retinoic acid, ETS and SRE. The promoter regulates downstream major IE genes which have a critical role in reactivation from latency and acute infection.

Since HNE is known to affect most of the respective signaling pathways and expression of several other genes relevant to the cellular stress response and growth control (Zarkovic, 2003; Leonarduzzi et al., 2004), the aim of our study was to analyze if this particular aldehyde could also affect the CMV-1 promoter.

\section{MATERIALS AND METHODS}

Cell cultures and transfection. The 293 human embryonic kidney cells (HEK293), a kind gift from Dr. Andreja Ambriovic Ristov, were cultured at $37^{\circ} \mathrm{C}$ in Dulbecco's modified Eagle's medium (DMEM) supplemented with $10 \%$ fetal calf serum (FCS, Gibco BRL/ Life Technologies, New York, NY, USA) and 1\% penicillin/streptomycin (Gibco) in a humidified atmosphere.

In the transfection experiment we used the pCDNA3 plasmid with a fusion gene encoding Toll-like receptor 4 (TLR4) with yellow fluorescent protein (YFP) that was cloned under the control of CMV-1 promoter (pCMV1TLR4-YFP, a kind gift from Dr. Alberto Visintin). TLR4 is a transmembrane receptor which detects lipopolysaccharides derived from bacteria and activates innate immunity. Given that the main goal of this work was to elucidate the HNE influence on CMV-1 promoter induction, we used the fusion protein since $\mathrm{HNE}$ has no stimulating but inhibiting effect on the TLR4 activation (Kim et al., 2009).

Transient transfection was performed using Lipofectamine $^{\mathrm{TM}}$ reagent according to the manufacturer's procedures (Invitrogen). Cells were plated at $7 \times 10^{4}$ cells per well in 96-well microcytoplates and incubated for 24 h. Cells were washed once in PBS (phosphate-buffered saline) and transfected for $3 \mathrm{~h}$ in $70 \mu \mathrm{L}$ of serum-free DMEM medium containing $0.5 \mu \mathrm{L}$ of Lipofectamine and $0.075 \mu \mathrm{g}$ of pCMV1-TLR4-YFP (Flo et al., 2002). Afterwards the transfection medium was removed, replaced with DMEM containing 10\% FCS and left over night. The plasmid used was isolated using QIA prep Spin Miniprep Kit (Qiagen). The next day the cells were treated with acrolein (Sigma, USA), HNE, hydrogen peroxide or left untreated as control at $37^{\circ} \mathrm{C}$ in a humidified air atmosphere with $5 \% \mathrm{CO}_{2}$ for $4 \mathrm{~h}$ and $24 \mathrm{~h}$.

$\mathrm{HNE}$, acrolein and $\mathrm{H}_{2} \mathrm{O}_{2}$ treatment. Prior to treatment the cells were left in serum-free medium for $1 \mathrm{~h}$. $\mathrm{HNE}$, acrolein or $\mathrm{H}_{2} \mathrm{O}_{2}$ were freshly prepared before each experiment and used in several concentrations in DMEM medium (2\% FCS). The concentrations used are expressed as equivalent per $2 \times 10^{4}$ cells.

HNE, in the form of 4-hydroxy-2-nonenal-dimethylacetal (HNE-DMA), was kindly provided by the Institute of Molecular Biology, Biochemistry and Microbiology (Graz, Austria). Prior to the experiment, it was activated with $1 \mathrm{mM} \mathrm{HCl}$ (Kemika, Croatia) for $2 \mathrm{~h}$. The concentration of HNE was determined by spectrophotometry (Shimadzu UV-1601 spectrophotometer) (Zivkovic et al., 2005).
Transfected HEK293 cells were treated with four different concentrations of $\operatorname{HNE}(8,16,24$ and $32 \mu \mathrm{M})$, acrolein $(8,16,32$ and $48 \mu \mathrm{M})$ and $\mathrm{H}_{2} \mathrm{O}_{2}(10,25,50$ and $100 \mu \mathrm{M}$ ) for $4 \mathrm{~h}$ and $24 \mathrm{~h}$ at $37^{\circ} \mathrm{C}$ in a humidified air atmosphere with $5 \% \mathrm{CO}_{2}$. Transfected HEK293 cells treated with DMEM medium served as control.

Cell viability assay. Cell viability was determined after the treatment with $\mathrm{HNE}$, acrolein or $\mathrm{H}_{2} \mathrm{O}_{2}$. The MTT-related colorimetric assay (EZ4U; Biomedica, Austria) was used to determine cell growth and viability, according to the manufacturer's instructions. The method was based on the fact that living cells are capable of reducing less colored tetrazolium salts into intensely colored formazan derivatives. This reduction process requires functional mitochondria, which are inactivated within a few minutes after cell death.

In order to determine $\mathrm{LD}_{50}$ (dose that kills $50 \%$ of cells), the cells were treated with $\mathrm{HNE}$, acrolein or $\mathrm{H}_{2} \mathrm{O}_{2}$ for $4 \mathrm{~h}$ prior to MTT assay. The HNE, acrolein and $\mathrm{H}_{2} \mathrm{O}_{2}$ concentrations corresponding to the respective $\mathrm{LD}_{50}$ values were further used in experiments with YFP expression. HNE concentrations below $\mathrm{LD}_{50}$ were also further used in the induction experiment. Therefore, the viability of cells was also analysed after $24 \mathrm{~h}$ of treatment for the cultures treated with respective $\mathrm{LD}_{50}$ doses of $\mathrm{HNE}$, acrolein or $\mathrm{H}_{2} \mathrm{O}_{2}$ and for cultures treated with $\mathrm{HNE}$ concentrations below $\mathrm{LD}_{50}$ to evaluate the effects of these treatments on the CMV-1 expression in the viable cells. Briefly, after the treatment the medium was removed and $200 \mu \mathrm{l}$ of fresh Hanks' balanced salt solution (HBSS) and $20 \mu \mathrm{l}$ of the tetrazolium agent were added to each well. After $2 \mathrm{~h}$ of incubation, plates were scanned in a microplate reader (Easy-Reader $400 \mathrm{FW}$, SLT Lab Instruments $\mathrm{GmbH}$, Austria) at $450 \mathrm{~nm}$.

Effect of $\mathrm{HNE}$, acrolein and $\mathrm{H}_{2} \mathrm{O}_{2}$ on CMV-1 promoter activation. After four or $24 \mathrm{~h}$ of treatment the effect of $\mathrm{LD}_{50}$ of $\mathrm{HNE}$, acrolein or $\mathrm{H}_{2} \mathrm{O}_{2}$ on CMV-1 promoter activity was checked. Fluorescence intensity was measured with a Cary Eclipse fluorescence spectrophotometer (Varian) with excitation at $514 \mathrm{~nm}$ and emission detection at $527 \mathrm{~nm}$. Arbitrary relative fluorescence units (RFU) were based directly on fluorescence intensity.

The fluorescence intensity was also checked for treatments with HNE concentrations below $\mathrm{LD}_{50}$.

Statistics. The results obtained are shown as the mean \pm SE for quadruplicates of cultures. The statistical significance was assessed using the Student's $t$-test and Chi-square test. Differences with values of $P<0.05$ were considered statistically significant.

\section{RESULTS}

HEK293 cells were transiently transfected with pCMV1-TLR4-YFP with transfection efficiency above $80 \%$. Cell viability of transfected HEK293 cells was determined $4 \mathrm{~h}$ after $\mathrm{HNE}$, acrolein or $\mathrm{H}_{2} \mathrm{O}_{2}$ treatment (Fig. 1). $\mathrm{HNE}$ and $\mathrm{H}_{2} \mathrm{O}_{2}$ decreased the cell viability in a concentration-dependent manner. In contrast, low concentrations of acrolein (8 and $16 \mu \mathrm{M}$ ) significantly increased the viability of transfected HEK293 cells $(P<0.05)$. However, after the treatment with higher acrolein concentrations the viability of cells was decreased $(P<0.05)$ when compared to control untreated cultures. The obtained results allowed determination of the $\mathrm{LD}_{50}$ concentrations for each treatment. Accordingly, the following $\mathrm{LD}_{50}$ concentrations were further used to treat 


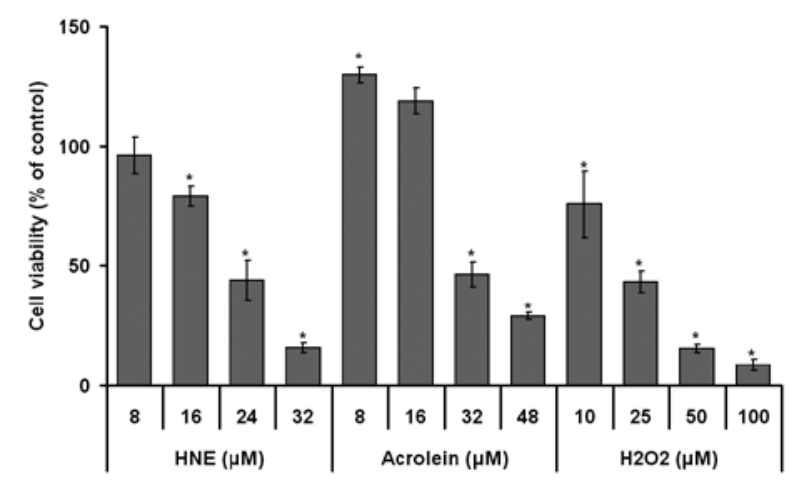

Figure 1. Cell viability of transiently transfected HEK293 cells after $4 \mathrm{~h}$ treatment with $\mathrm{HNE}$, acrolein or $\mathrm{H}_{2} \mathrm{O}_{2}$.

Cell viability is presented as percentage of control untreated transfected HEK293 cells. Mean values $( \pm$ SE) for triplicates are given: $\left(^{*}\right)$ significance $P<0.05$ in comparison to control untreated HEK293 transfected cells.

the cells: $\mathrm{HNE}-24 \mu \mathrm{M}$, acrolein $-32 \mu \mathrm{M}$ and $\mathrm{H}_{2} \mathrm{O}_{2}$ $-25 \mu \mathrm{M}$.

The effects of $\mathrm{LD}_{50}$ concentrations of HNE, acrolein or $\mathrm{H}_{2} \mathrm{O}_{2}$ on the activation of CMV-1 promoter are shown in Fig. 2. The results are presented as RFU normalized to cell viability (RFU/cell viability). It can be seen that the $\mathrm{LD}_{50}$ concentration of HNE had the strongest effect $(P<0.05)$ on CMV-1 promoter activation resulting in a three-fold increase in YFP expression after $4 \mathrm{~h}$ or $24 \mathrm{~h}$ of treatment. Hydrogen peroxide at $\mathrm{LD}_{50}$ increased slightly $(50 \%)$ but also significantly $(P<0.05)$ the YFP expression after $4 \mathrm{~h}$ and $24 \mathrm{~h}$. However, treatment with acrolein $\mathrm{LD}_{50}$ did not significantly affect YFP expression.

The induction efficiencies obtained in the experiments using HNE concentrations below $\mathrm{LD}_{50}(8$ and $16 \mu \mathrm{M}$ HNE), in which the viability of the transfected cells was not strongly affected, are shown in Fig. 3. As it can be seen, treatment with $8 \mu \mathrm{M}$ HNE had no influence $(P>0.05)$ on CMV-1 promoter induction. However, treatment with $16 \mu \mathrm{M}$ HNE slightly $(12 \%)$ but significantly $(P<0.05)$ induced the CMV-1 promoter after $4 \mathrm{~h}$ while after $24 \mathrm{~h}$ it had a very prominent effect $(P<0.05)$ on CMV-1 promoter activation resulting in a two-fold increase of YFP expression.

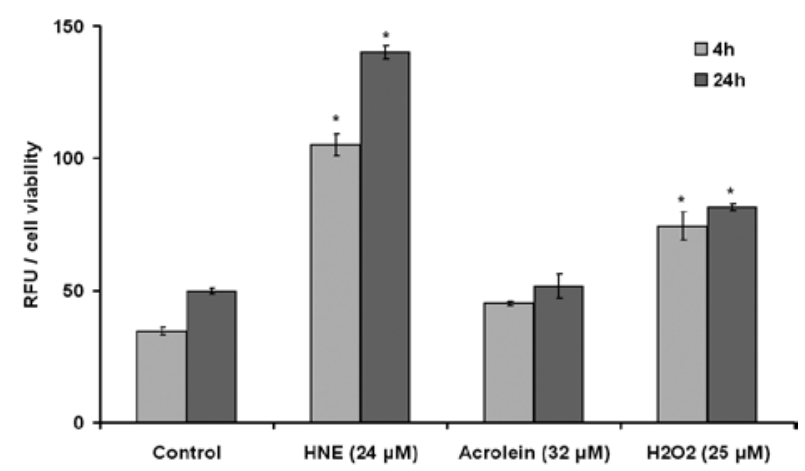

Figure 2. Effect of $\mathrm{HNE}$, acrolein or $\mathrm{H}_{2} \mathrm{O}_{2}$ on $\mathrm{CMV}-1$ promoter activation after $4 \mathrm{~h}$ or $24 \mathrm{~h}$ of treatment.

Results are presented as RFU normalized to cell viability (RFU/cell viability). Mean values $( \pm \mathrm{SE})$ for triplicates are given: $\left({ }^{*}\right)$ significance $P<0.05$ in comparison to control untreated HEK293 transfected cells.

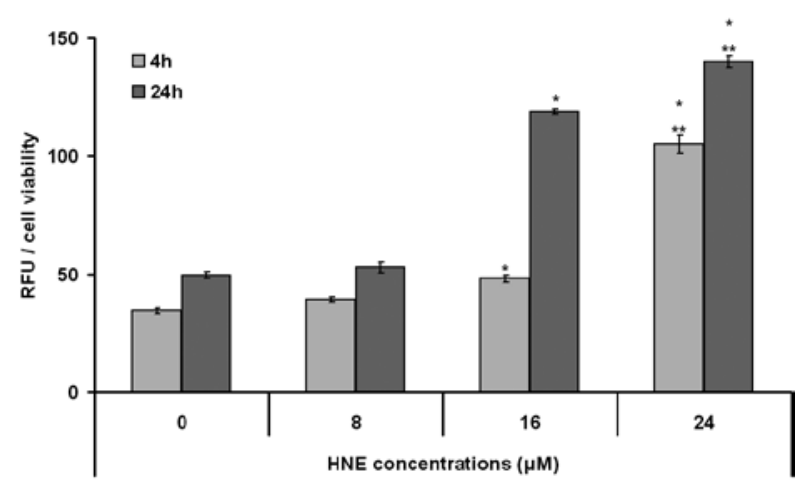

Figure 3. CMV-1 induction by various HNE after $4 \mathrm{~h}$ or $24 \mathrm{~h}$. Results are presented as RFU normalized to cell viability (RFU/ cell viability). Mean values $( \pm S E)$ for the triplicates are given: $\left.{ }^{*}\right)$ significance $P<0.05$ in comparison to control untreated HEK293 transfected cells, $\left.{ }^{* *}\right)$ significance $P<0.05$ in comparison to results obtained for16 $\mu$ M HNE.

\section{DISCUSSION}

The induction of CMV promoter by $\mathrm{H}_{2} \mathrm{O}_{2}$ shown here is consistent with the previous results reported by Speir (2000). That study showed that $\mathrm{H}_{2} \mathrm{O}_{2}$ treatment can induce MIEP (major immediate early promoter) transcription in smooth muscle cells. This was abolished by the addition of antioxidants, supporting the hypothesis of ROS involvement as important signaling mechanism of CMV promotion.

In the present paper we further show strong effects of the major bioactive marker of lipid peroxidation, the aldehyde HNE, on CMV promoter induction. This particular effect of HNE probably occurred due to the HNE-specific induction of transcription factors and was not observed for acrolein, which is another bioactive aldehyde produced by lipid peroxidation. It is well known that HNE can induce activation of several transcription factors including activator protein 1 (AP-1), a well known redox-sensitive transcription factor that regulates the activation of transcription of a variety of genes (Liu et al., 2001). The activity of AP-1 is regulated by the phosphorylation of MAPKs that include JNK. It has also been reported that HNE may activate JNK by its direct binding (Parola et al., 1998) or through the redox-sensitive MAPK kinase cascade (Uchida et al., 1999). However, the influence of HNE on NF- $x \mathrm{~B}$, another redox-sensitive transcription factor, remains unclear. Some researchers have shown that HNE can inhibit NF- $x \mathrm{~B}$ activation through inhibition of $\mathrm{I} x \mathrm{~B}$ phosphorylation by di-

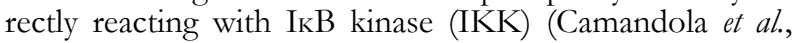
1997; 2000; Page et al., 1999; Vaillancourt et al., 2007), while others have reported its stimulatory effect (Ruef et al., 2001; Lee et al., 2008). While HNE is of continuous interest among researchers studying cell signaling and epigenomic aspects of oxidative stress (Zarkovic N, 2003), a detailed mechanism of HNE action as a regulatory factor has yet to be elucidated.

We cannot infer yet which of the above-mentioned transcription factors is involved in this HNE-induced CMV promoter activation because this promoter has binding sites for AP-1 and NF- $x \mathrm{~B}$ both. Therefore, in the continuation of this research we will mutate binding sites for these transcription factors in the CMV-IE promoter to distinguish which one is crucial for the observed enhancing effects of HNE. 
It should also be mentioned that the transfection procedure is always a stress for the cell, hence it might also be associated with mild, non-toxic oxidative stress resulting in HNE production due to peroxidation of membrane lipids, which could consequently affect the CMV promoter. Since CMV promoter is commonly used in transfection studies, it seems likely that this bioactivity of HNE might also be relevant for other transfection studies. Such CMV stimulation by HNE could influence the transcription of other target genes, in particular if occurring in cells with weak antioxidant capacities or if combined with additional stressors. Yet, this assumption has to be further evaluated in more detail. In the case of our study, the main goal was to elucidate the influence of exogenous $\mathrm{HNE}$ on $\mathrm{CMV}-1$ promoter induction in HEK293 cells so we may conclude with certainty that the effects of $\mathrm{HNE}$ treatments were specific to the CMV-1 promoter and were not influenced by endogenous HNE. We used the fusion protein of TLR4 because HNE does not stimulate its expression (Kim et al., 2009). However, it is impossible to completely exclude the possible influence of $\mathrm{HNE}$ on specific activation of TLR4 since we did not use a vector encoding solely the YFP-reporter protein. When used at the low concentration of $8 \mu \mathrm{M}$, which is still above a physiological one for cultured cells even if mildly stressed by lipid peroxidation (Zarkovic, 2003; Borovic et al., 2006), HNE was not effective. This indicates that only supraphysiological levels of $\mathrm{HNE}$ are able to induce CMV promoter. This also suggests that in case of latent CMV infection conditions that might activate the CMV, such as chemotherapy, radiotherapy, ischemia/reperfusion or inflammatory processes (Scholz et al., 1996; Spier, 2000; Vereecque et al., 2003), induce the CMV because of their pathophysiology involving oxidative stress and increased HNE production. This possibility has to be further studied, in particular since recent data also indicate that CMV infection itself provokes cellular oxidative stress inducing a vicious circle. Hence, possible antioxidant treatments were also proposed as adjuvant therapy for CMV infections (Cintal et al., 2000; Dhaunsi et al., 2003; Gnana-Prakasam et al., 2003).

It could also be possible that HNE could have a dual, concentration-dependent effect on the CMV-IE promoter. Namely, the dependence of the CMV promoter activity on cAMP concentration was reported several years ago (Zhang et al., 2003). Cyclic AMP is also a well known second messenger involved in cell signaling cascades, which activates various effector proteins. This suggestion is further supported by the fact that HNE has diverse effects depending on its concentration, also affecting adenylate cyclase if used at micromolar concentrations (Paradisi et al., 1985). It has been shown that low levels of HNE promote proliferation (Ruef et al., 1998; Cheng et al., 1999) while higher concentrations induce differentiation and apoptosis (Kruman et al., 1997; Cheng et al., 1999; 2001; Dianzani et al., 1999; Soh et al., 2000). In the study presented here, we tested only the $\mathrm{LD}_{50}$ concentration and several lower concentrations, so further studies should be done before making final conclusions about this assumption.

In conclusion, our results suggest that transfection experiments should consider possible effects of transfection-induced stress and consequential membrane lipid peroxidation-generating HNE. Stimulation of the CMV promoter by HNE may be of practical importance also for better monitoring and treatment of CMV infections.

\section{Acknowledgements}

The authors thank Dr. Alberto Visintin and Dr. Brian Monks from University of Massachusetts Medical School (Worchester, USA) for their help and plasmid description.

The study was supported by Croatian Ministry of Science, Education and Sports and by COST B35 Action.

\section{REFERENCES}

Awasthi YC, Yang Y, Tiwari NK, Patrick B, Sharma A, Li J, Awasthi S (2004) Regulation of 4-hydroxynonenal-mediated signaling by glutathione S-transferases. Free Radic Biol Med 37: 607-619.

Bartosz G (2009) Reactive oxygen species: destroyers or messengers? Biochem Pharmacol 77: 1303-1315.

Borovic Sunjic S, Cipak A, Rabuzin F, Wildburger R, Zarkovic N (2005) The influence of 4-hydroxy-2-nonenal on proliferation, differentiation and apoptosis of human osteosarcoma cells. Biofactors, 24: 141-148.

Borovic S, Rabuzin F, Waeg G, Zarkovic N (2006) Enzyme-linked immunosorbent assay for 4-hydroxynonenal-histidine conjugates. Free Radic Res 40: 809-820.

Braughler JM, Hall ED (1989) Central nervous system trauma and stroke. I. Biochemical considerations for oxygen radical formation and lipid peroxidation. Free Radic Biol Med 6: 289-301.

Camandola S, Scavazza A, Leonarduzzi G, Biasi F, Chiarpotto E, Azzi A, Poli G (1997) Biogenic 4-hydroxy-2-nonenal activates transcription factor AP-1 but not NF-kappa B in cells of the macrophage lineage. Biofactors 6: 173-179.

Camandola S, Poli G, Mattson MP (2000) The lipid peroxidation product 4-hydroxy-2,3-nonenal inhibits constitutive and inducible activity of nuclear factor kappa B in neurons. Brain Res Mol Brain Res 85: 53-60.

Cheng JZ, Sharma R, Yang Y, Singhal SS, Sharma A, Saini MK, Singh SV, Zimniak P, Awasthi S, Awasthi YC (2001) Accelerated metabolism and exclusion of 4-hydroxynonenal through induction of RLIP76 and hGST5.8 is an early adaptive response of cells to heat and oxidative stress. J Biol Chem 276: 41213-41223.

Cheng JZ, Singhal SS, Sharma A, Saini M, Yang Y, Awasthi S, Zimniak P, Awasthi YC (2001) Transfection of mGSTA4 in HL-60 cells protects against 4-hydroxynonenal-induced apoptosis by inhibiting JNK-mediated signaling. Arch Biochem Biophys 392: 197-207.

Cheng JZ, Singhal SS, Saini M, Singhal J, Piper JT, Van Kuijk FJ, Zimniak P, Awasthi YC, Awasthi S (1999) Effects of mGST A4 transfection on 4-hydroxynonenal-mediated apoptosis and differentiation of K562 human erythroleukemia cells. Arch Biochem Biophys 372: $29-36$.

Cinatl Jr J, Vogel J-U, Kotchetkov R, Scholz M, Doerr HW (2000) Proinflammatory potential of cytomegalovirus infection. Specific inhibition of cytomegalovirus immediate-early expression in combination with antioxidants as a novel treatment strategy? Intervirology 42: 419-424.

Dhaunsi GS, Kaur J, Turner RB (2003) Role of NADPH oxidase in cytomegalovirus-induced proliferation of human coronary artery smooth muscle cells. J Biome Sci 10: 505-509.

Dianzani MU, Barrera G, Parola M (1999) 4-Hydroxy-2,3-nonenal as a signal for cell function and differentiation. Acta Biochim Pol 46: 61-75.

Esterbauer H, Schaur RJ, Zollner H (1991) Chemistry and biochemistry of 4-hydroxynonenal, malonaldehyde and related aldehydes. Free Radic Biol Med 11: $81-128$.

Flo TH, Ryan L, Latz E, Takeuchi O, Monks BG, Lien E, Halaas $\varnothing$, Akira S, Skjåk-Braek G, Golenbock DT, Espevik T (2002) Involvement of toll-like receptor (TLR) 2 and TLR4 in cell activation by mannuronic acid polymers. I Biol Chem 277: 35489-35495.

Gnana-Prakasam JP, Zhang M, Martin, PM, Atherton SS, Smith SB, Ganapathy V (2009) Expression of the iron-regulatory protein haemojuvelin in retina and its regulation during cytomegalovirus infection. Biochem J 419: 533-543.

Hall ED, Braughler JM (1989) Central nervous system trauma and stroke. II. Physiological and pharmacological evidence for involvement of oxygen radicals and lipid peroxidation. Free Radic Biol Med 6: $303-313$.

Hartley DP, Ruth JA, Petersen DR (1995) Hepatocellular metabolism of 4-hydroxynonenal by alcohol dehydrogenase, Arch Biochem Biophys 316: $197-205$.

Kim YS, Park ZY, Kim SY, Jeong E, Lee JY (2009) Alteration of Tolllike receptor 4 activation by 4-hydroxy-2-nonenal mediated by the suppression of receptor homodimerization. Chem Biol Interact 182: 59-66. 
Kreuzer T, Grube R, Wutte A, Zarkovic N, Schaur RJ (1998) 4-Hydroxynonenal modifies the effects of serum growth factors on the expression of the c-fos proto-oncogene and the proliferation of HeLa carcinoma cells. Free Radic Biol Med 25: 42-49.

Kruman I, Bruce-Keller AJ, Bredesen D, Waeg G, Mattson MP (1997) Evidence that 4-hydroxynonenal mediates oxidative stress-induced neuronal apoptosis. I Neurosi 17: 5089-5100.

Lee SI, Seo KW, Yun MR, Bae SS, Lee WS, Hong KW, Kim CD (2008) 4-Hydroxynonenal enhances MMP-2 production in vascular smooth muscle cells via mitochondrial ROS-mediated activation of the Akt/NF-xB signaling pathways. Free Radic Biol Med 45: 14871492.

Leonarduzzi G, Robbesyn F, Poli G (2004) Signaling kinases modulated by 4-hydroxynonenal. Free Radic Biol Med 37: 1694-1702.

Liu R-M, Borok Z, Forman HJ (2001) 4-Hydroxy-2-nonenal increases gamma-glutamylcysteine synthetase gene expression in alveolar epithelial cells. Am J Respir Cell Mol Biol 24: 499-505.

Mocarski ES (1996) Cytomegaloviruses and their replication. In: Fields virology. Fields BN, Knipe DM, Howley PM, Chanock RM, Melnick JL, Monath TP, Roizman B, Straus SE, eds, pp 2447-2492, Lippincott-Raven, Philadelphia.

Numazaki K, Asanuma H, Chiba S (1995) Latent infection and reactivation of human cytomegalovirus. Serodiag Immun Inf D 7: 70-74.

Page S, Fischer C, Baumgartner B, Haas M, Kreusel U, Loidl G, Hayn M, Ziegler-Heitbrock HW, Neumeier D, Brand K (1999) 4-Hydroxynonenal prevents NF- $\varkappa \mathrm{B}$ activation and tumor necrosis factor expression by inhibiting I $\mathrm{B}$ phosphorylation and subsequent proteolysis. I Biol Chem 274: 11611-11618.

Paradisi L, Panagini C, Parola M, Barrera G, Dianzani MU (1985) Effects of 4-hydroxynonenal on adenylate cyclase and 5 '-nucleotidase activities in rat liver plasma membranes. Chem Biol Interact 53: 209-217.

Parola M, Robino G, Marra F, Pinzani M, Bellomo G, Leonarduzzi G, Chiarugi P, Camandola S, Poli G, Waeg G, Gentilini P, Dianzani MU (1998) HNE interacts directly with JNK isoforms in human hepatic stellate cells. J Clin Invest 102: 1942-1950.

Rinaldi M, Barrera G, Aquino A, Spinsanti P, Pizzimenti S, Farace MG, Dianzani MU, Fazio VM (2000) 4-Hydroxynonenal-induced MEL cell differentiation involves PKC activity translocation. Biochem Biophys Res Commun 272: 75-80.

Ruef J, Rao GN, Li F, Bode C, Patterson C, Bhatnagar A, Runge MS (1998) Induction of rat aortic smooth muscle cell growth by the lipid peroxidation product 4-hydroxy-2-nonenal. Circulation 97: 1071-1078.

Ruef J, Moser M, Bode C, Kübler W, Runge MS (2001) 4-Hydroxynonenal induces apoptosis, NF- $x$ B-activation and formation of 8 -isoprostane in vascular smooth muscle cells. Basic Res Cardiol 96: $143-150$.

Scholz M, Cinatl J, Gross V, Vogel JU, Blaheta RA, Freisleben HJ, Markus BH, Doerr HW (1996) Impact of oxidative stress on human cytomegalovirus replication and on cytokine-mediated stimulation of endothelial cells. Transplantation 61: 1763-1770.

Scholz M, Doerr HW, Cinatl J (2001) Inhibition of cytomegalovirus immediate early gene expression: a therapeutic option? Antiviral Res 49: 129-145.
Soh Y, Jeong KS, Lee IJ, Bae MA, Kim YC, Song BJ (2000) Selective activation of the c-Jun $\mathrm{N}$-terminal protein kinase pathway during 4-hydroxynonenal-induced apoptosis of PC12 cells. Mol Pharmacol 58: $535-541$.

Sovic A, Borovic S, Loncaric I, Kreuzer T, Zarkovic K, Vukovic T, Wäg G, Hrascan R, Wintersteiger R, Klinger R, Zurak N, Schaur RJ, Zarkovic N (2001) The carcinostatic and proapoptotic potential of 4-hydroxynonenal in HeLa cells is associated with its conjugation to cellular proteins. Anticancer Res, 21: 1997-2004.

Speir E (2000) Cytomegalovirus gene regulation by reactive oxygen species. Agents in atherosclerosis. Ann N Y Acad Sci USA 899: 363-374.

Uchida K (2003) 4-Hydroxy-2-nonenal: a product and mediator of oxidative stress. Prog Lipid Res 42: 318-343.

Uchida K, Shiraishi M, Naito Y, Torii Y, Nakamura Y, Osawa T (1999) Activation of stress signaling pathways by the end product of lipid peroxidation. 4-Hydroxy-2-nonenal is a potential inducer of intracellular peroxide production. J Biol Chem 274: 2234-2242.

Vaillancourt F, Morquette B, Shi Q, Fahmi H, Lavigne P, Di Battista JA, Fernandes JC, Benderdour M (2007) Differential regulation of cyclooxygenase-2 and inducible nitric oxide synthase by 4-hydroxynonenal in human osteoarthritic chondrocytes through ATF2/CREB-1 transactivation and concomitant inhibition of NF-kappaB signaling cascade. J Cell Biochem 100: 1217-1231.

Vereecque R, Saudemont A, Depil, S, Quesnel B (2003) Chemotherapy increases transgene expression in leukemic cells. J Gene Med 5: 852-859.

Zarkovic N (2003) 4-Hydroxynonenal as a bioactive marker of pathophysiological processes. Mol Aspects Med 24: 281-291.

Zarkovic K (2003) 4-Hydroxynonenal and neurodegenerative diseases. Mol Aspects Med 24: 293-303.

Zarkovic N, Ilic Z, Jurin M, Schaur RJ, Puhl H, Esterbauer H (1993) Stimulation of HeLa cell growth by physiological concentrations of 4-hydroxynonenal. Cell Biochem Funct 11: 279-286.

Zarkovic N, Schaur RJ, Puhl H, Jurin M, Esterbauer H (1994) Mutual dependence of growth modifying effects of 4-hydroxy-nonenal and fetal calf serum in vitro. Free Radic Biol Med 16: 877-884.

Zarkovic N, Tillian MH, Schaur RJ, Waeg G, Jurin M, Esterbauer H (1995) Inhibition of melanoma B16-T10 growth by lipid peroxidation product 4-hydroxynonenal, Cancer Biother 10: 153-156.

Zarkovic N, Zarkovic K, Schaur RJ, Stolc S, Schlag G, Redl H, Waeg G, Borovic S, Loncaric I, Juric G, Hlavka V (1999) 4-Hydroxynonenal as a second messenger of free radicals and growth modifying factor. Life Sci 65: 1901-1904.

Zivkovic M, Zarkovic K, Skrinjar Lj, Waeg G, Poljak-Blazi M, Borovic S, Schaur RJ, Zarkovic N (2005) A new method for detection of HNE-histidine conjugates in rat inflammatory cells. Croat Chem Acta 78: 91-98.

Zhang B, Liu Y, Harbrecht BG (2003) Cyclic AMP regulate adenovirus mediated inducible nitric oxide synthase expression and CMV promoter activity in cultured hepatocytes. Nitric Oxide 8: 262-265.

Zollner H, Schaur RJ, Esterbauer H (1991) Biological activities of 4-hydroxyalkenals In: Oxidative stress: oxidants and antioxidants, $\mathrm{H}$. Sies, ed, pp 319-336, Academic Press, London. 